\title{
Retrospective study of metal contamination time trends in the French part of the Bay of Biscay
}

\author{
Bernard Boutier ${ }^{\mathrm{a},{ }^{*}}$, Jean-Yves Quintin ${ }^{\mathrm{b}}$, Emmanuelle Rozuel $^{\mathrm{a}}$, Auger Dominique ${ }^{\mathrm{a}}$ \& Jane Bretaudeau- \\ Sanjuan $^{a}$ \\ a IFREMER, BE-CM, Rue de l'île d'Yeu, BP21105, 44311 Nantes Cedex3, France \\ b IFREMER BREST, Dyneco, BP70 29280 Plouzané, France \\ *: Corresponding author : B. Boutier, email address : bboutier@ifremer.fr
}

\begin{abstract}
:
Two cores were sampled in the Bay of Biscay: one a few miles off the Gironde estuary (pointe de la Coubre), the other near the Spanish border (Capbreton canyon) to study past variations in sediment contamination. Radiochronology $\left({ }^{210} \mathrm{~Pb},{ }^{137} \mathrm{Cs}\right)$ and total metal determinations by ICP-MS allowed the study of time trends for metal concentrations in sediment. Off the Gironde, during the time interval recorded by the core (1958-1999), all metal concentrations remained less than OSPAR background values. Some variations occurred along the $\mathrm{Cd}$ and $\mathrm{Zn}$ profiles, which may correspond to a very attenuated signal from the Gironde outputs. This suggests that this area was not submitted to any significant anthropogenic input of metals between 1958 and 1999. In the canyon of Capbreton, the undisturbed part of the core recorded the influence of surface deposition between 1977 and 1999 . From as early as 1977 high lead and mercury concentrations were noticed. Mercury concentrations increased until 1992, then decreased until 1999. This marks a drop of inputs in 1992, but the final concentration remained elevated. Lead had important concentrations (more than twice the OSPAR reference) all along the core and began to decrease only in the upper level of the unmixed layer. This shows a late (near 1998) drop of lead inputs. Other metals (Cd, Cu, Zn, Ni, Cr) stayed at a much lower level: less than the OSPAR reference for $\mathrm{Cu}, \mathrm{Cr}$ and $\mathrm{Ni}$ or not far from the OSPAR reference for $\mathrm{Cd}$ and $\mathrm{Zn}$.
\end{abstract}

Keywords: sediment, metal contamination, dating, cores, time trends 


\section{Introduction}

One of the aims of the French monitoring program R.N.O. (national observation network for marine environment quality), which became R.O.C.C..H. (Observation Network of Chemical Contamination) in 2008, is to evaluate trends in contamination of different matrices of the French littoral. The aim of this work is to study the evolution of metal contamination of the sediment on two stations of the Bay of Biscay along the last part of the twentieth century. Two cores were taken in two areas supposed to be exposed to contaminant inputs: one near the Gironde estuary, which is heavily contaminated by Cadmium ([1], [2], [3]) the other in the canyon of Capbreton, not far from the Basque estuaries which show heavy metallic contamination. ( [4], [5]).

Sediment cores are suitable to study temporal variations of contamination of sediment [6], provided that sediment layers are regularly deposited and do not undergo mixing by burrowing organisms, currents, storms or trawling [7]. For regularly layered sediments, the depth of a horizon is directly linked to the time elapsed since deposit. Radiochronologic techniques, based in particular on the study of ${ }^{210} \mathrm{~Pb}$ and ${ }^{137} \mathrm{Cs}$ profiles allow to verify that these conditions are fulfilled in the sediment under study. They can also help to determine the parameters necessary for the retrospective study of trends (e.g. sedimentation rate) [8] [9].

The use of cores for the retrospective study of the contamination is also conditioned by the temporal stability of the concentration contaminant in a given layer upon burial. That is, diagenesis should not affect this element during burial [10]. Thorough examination of elements particularly sensitive to diagenetic processes (e.g. Mn, organic C, S, Co, Fe...) can ensure that the site under study is not too affected by diagenetic processes.

\section{Materials and methods}

\subsection{Sampling}

Two cores were taken (Figure1): station 10, on the 09/06/1999, 18 nautical miles off the Pointe de la Coubre $\left(45^{\circ} 42.13^{\prime} \mathrm{N}, 01^{\circ} 42.21^{\prime} \mathrm{W}\right)$, and station 17 on the $07 / 06 / 1999$ in the Capbreton canyon $\left(43^{\circ} 36.33^{\prime} \mathrm{N}, 01^{\circ} 47.23^{\prime} \mathrm{W}\right)$. Both cores were taken with a Reineck boxcore . The box $(29 \mathrm{~cm} \times 21 \mathrm{~cm}$ section, $42 \mathrm{~cm}$ height) was equipped with a sliding side which allowed a precise slicing of the undisturbed cores when pulled carefully downwards. The box was placed in a Plexiglas/stainless steel glove box to allow clean and precise slicing [11]. For metal analysis, samples were taken with a teflon spatula, placed in acid cleaned polystyrene vials and immediately frozen. Back in the lab, they were freeze dried.

The samples for the determination of radionucleides were placed in crystal polystyrene vials and frozen. Back in the lab, they were freeze dried and transferred into plastic containers suitable for gamma counting. Gamma activities were measured by the Laboratory of Measurement of the Radioactivity of the Environment (L.M.R.E, Institute for Protection and Nuclear Safety, I.P.S.N.) in Orsay (France).

\subsection{Analytical methods}

2.2.1. Metals.

$\mathrm{Cd}, \mathrm{Cr}, \mathrm{Cu}, \mathrm{Ni}$, and $\mathrm{Pb}$ were measured by flameless atomic absorption spectrophotometry after $\mathrm{HCl}-\mathrm{HNO} 3-\mathrm{HF}$ solubilization [12].

$\mathrm{Fe}, \mathrm{Mn}, \mathrm{Al}, \mathrm{Zn}$ were measured by flame atomic absorption spectrophotometry after the same digestion procedure. 
Mercury was analysed by AAS after calcination of the samples, gold trapping of $\mathrm{Hg}^{0}$, and thermal decomposition of the amalgam before vapour analysis. The whole procedure is automated in an AMA $254^{\circledR}$ analyser. [13]

Quality of the results was checked by including in each analytical series a reference sample from the National Research Council of Canada (NRCC) : BCSS1, MESS1,2,3 [14]. Our laboratory also participates in the international intercalibration exercises (QUASIMEME, I.A.E.A.)

\subsubsection{Radioelements.}

All the elements necessary to examine geochronology were determined by gamma spectrometry: ${ }^{210} \mathrm{~Pb}$ was characterized by its gamma-ray emission at $46.5 \mathrm{keV},{ }^{214} \mathrm{Bi}$ by its gamma-ray emission at $609.3 \mathrm{keV},{ }^{214} \mathrm{~Pb}$ at $351.9 \mathrm{keV},{ }^{137} \mathrm{Cs}$ at $661.7 \mathrm{keV}$. Unsupported (xs) ${ }^{210} \mathrm{~Pb}$ was calculated by subtracting the average of ${ }^{214} \mathrm{Bi}$ and ${ }^{214} \mathrm{~Pb}$ from total ${ }^{210} \mathrm{~Pb}$.

\subsection{Geochronology}

Sedimentation rates were estimated after [15] and [16]. The study was conducted using ${ }^{210} \mathrm{~Pb}$ and ${ }^{137} \mathrm{Cs}$. ${ }^{210} \mathrm{~Pb}$ is formed by the disintegration in the sediment of ${ }^{226} \mathrm{Ra}$, and the disintegration in the water column and in the atmosphere of ${ }^{222} \mathrm{Rn}$. The ${ }^{210} \mathrm{~Pb}$ formed by the second process is very quickly adsorbed onto the particles and settles to the sediment where it constitutes the unsupported ${ }^{210} \mathrm{~Pb}$ inventory $\left({ }^{210} \mathrm{~Pb}_{\mathrm{xs}}\right)$ which is used for dating. The ${ }^{210} \mathrm{~Pb}_{\mathrm{xs}}$ disintegrates in the sediment according to a first-order reaction $\mathrm{dA}=-\lambda \mathrm{Adt}$ $\left(A=\right.$ activity of ${ }^{210} \mathrm{~Pb}_{\mathrm{xs}}, \lambda=$ disintegration constant, $\mathrm{t}=$ time elapsed since depositing of the horizon). From this equation $\ln (A)=-\lambda t+C \quad(C=$ integration constant). Assuming that there is no mixing or compaction, $\mathrm{Z}=\mathrm{Kt}(\mathrm{Z}=$ depth of the horizon, $\mathrm{K}=$ sedimentation rate): $\mathrm{so}, \mathrm{t}=$ $Z / K$. In addition, the half-life $T_{1 / 2}$ and disintegration constant $\lambda$ are linked by:

$\ln 2=\lambda T_{1 / 2}$, or $\lambda=\ln 2 / T_{1 / 2}$. This leads to: $\ln (A)=-\left(\ln 2 / T_{1 / 2}\right) *(Z / K)+C$. Under these conditions, the graph of $\ln (A)$ vs depth is a straight line with a slope $P=-\ln (2) /\left(T_{1 / 2} * K\right)$, where $K=-\ln (2) /\left(P * T_{1 / 2}\right)$.

${ }^{137} \mathrm{Cs}$ was introduced into the environment by thermonuclear tests in 1952 , mean injections dating from 1963 [17], [18], [19]. The deepest horizon containing a significant activity of ${ }^{137} \mathrm{Cs}$ was therefore the surface sediment in 1952 or, if there was a mixed layer, it was at the bottom of this layer at that time.

\subsection{Treatment of data. correction to $5 \% \mathrm{Al}$}

Raw metal data are not suitable to study sediment results, because a certain number of natural parameters as grain size and clay content may significantly affect the metal concentrations in sediment. Several authors[20], [21], [22] proposed methods to take these parameters into account for the interpretation of metal concentrations in sediment monitoring programs. The correction procedure used here has been recommended by the Oslo and Paris commission to allow comparison between samples of different grain size or mineralogical composition. This procedure is described in details in [23]. In the present work all results are processed to calculate the concentration of the sample at $5 \% \mathrm{Al}$ concentrations. This procedure is used in the Cooperative Environment Monitoring Program (C.E.M.P.) of OSPAR. 


\section{Results}

\subsection{Core 10}

\subsubsection{Description and dating}

This core was sampled off the edge of La Coubre. The water depth at the sampling point was $52 \mathrm{~m}$. The core was $28 \mathrm{~cm}$ long. The percentage of particles less than $63 \mu \mathrm{m}$ is between 83 and $91 \%$, which is relatively homogeneous. The upper layer was covered by fine $(<63 \mu \mathrm{m})$ light grey material which was probably oxic. All deeper layers were dark and visibly anoxic. So the core from the subsurface $(1$ to $2 \mathrm{~cm})$ to the bottom is anoxic. The concentrations of particulate manganese ( $414 \mu \mathrm{g} / \mathrm{g}$ at the bottom, 438 in subsurface) does not vary by more than $10 \%$ all along the core under the surface layer. A significant enrichment is observed in the surface layer $(472 \mu \mathrm{g} / \mathrm{g})$ which may be caused by precipitation of manganese diffused from underlying anoxic horizons [10] , [24]

Particulate iron concentrations show a slight enrichment in surface, which also suggests moderate reprecipitation.

All this does not reflect intense diagenetic processes along the core.

Small concentration variations are well damped by correction to $5 \% \mathrm{Al}$ (Figure2).

Water percentages below the mixed layer $(5 \mathrm{~cm})$ vary between $42.3 \%(6 \mathrm{~cm})$ and $49.1 \%$ $(14 \mathrm{~cm})$. As these variations are small, we will not take compaction into account in calculating the sedimentation rate.

Organic carbon concentrations vary between 11.5 and $14.5 \mathrm{mg} / \mathrm{g}$ all along the core.

The ${ }^{210} \mathrm{~Pb}_{\mathrm{xs}}$ presents a profile in two parts (fig. 3). In the five top-most centimetres the ${ }^{210} \mathrm{~Pb}_{\mathrm{xs}}$ concentration is almost constant, reflecting an intense mixing of this layer. In the lower levels, the relationship between $\ln ^{210} \mathrm{~Pb}_{\mathrm{xs}}$ and depth $\mathrm{x}$ is well described by

In ${ }^{210} \mathrm{~Pb}_{\mathrm{xs}}=-0.056 \mathrm{x}+4.57\left(\mathrm{R}^{2}=0.90\right)(\mathrm{n}=12)$. This linear relation allows to calculate $\mathrm{a}$ sedimentation rate: $K=-\ln 2 /\left(P * T_{1 / 2}\right)$, where $P$ is the regression coefficient between ${ }^{210} \mathrm{~Pb}_{\mathrm{xs}}$ and depth, and $\mathrm{T}$ the half life of ${ }^{210} \mathrm{~Pb}_{\mathrm{xs}}$. Here, $\mathrm{P}=0.056$ and $\mathrm{T}=22.2$ (years), so

$\mathrm{K}=0.56 \mathrm{~cm} /$ year.

This value is very similar to which was found by Lesueur et al. [25 ] in the the West Gironde mud patch, not far from station 10 .

The bottom layer left the mixed box (28-5)/0.56=41years before sampling. So this core gives informations about the inputs to the sediment from 1958 to 1999. Some caution must be taken in the interpretation of the core because of the mixed layer which introduces damping in the input signal before recording in the unmixed box.

Aluminum concentrations vary slightly on the profile (fig.2). There are five relative extrema on $\mathrm{Al}$, which has led us to discuss Al-corrected metal profiles to take this natural variability into account.

\subsubsection{Metal concentrations}

\subsubsection{Cadmium and zinc}

The presence of a mixed layer makes it difficult to establish a precise chronology of metal inputs. We consider that the sediment is made up of an upper well mixed box ${ }^{210} \mathrm{~Pb}_{\mathrm{xs}}$ profiles support this hypothesis) above a non-mixed layer where ${ }^{210} \mathrm{~Pb}$ undergoes an exponential decrease with depth. In this model an influx of contaminant in the surface layer is immediately distributed in the entire well mixed box [26].

If the non- mixed horizons are not particularly contaminated, then an increase in contaminant concentration in depositing particles will be noticed in the well mixed box. (Figure 4) When the sediment of the well mixed box comes out to the non mixed box, in the absence of diagenetic processes, the augmentation of the concentration in the well mixed box is transferred to the upper layer of the non mixed box. If the input of contaminant to the 
sediment continues, the concentration in the whole mixed box increases, which produces an increase of the concentrations in the upper levels of the non mixed box upon burial. The concentrations in the upper part of the unmixed layer will keep increasing until the concentration of depositing particles becomes equal to the mean concentration of the mixed box, which stops the augmentation of concentration in the mixed box. If it becomes lower, a decrease is noticed in the non mixed layers.

The raw and normalized profiles are very similar for $\mathrm{Cd}$ and $\mathrm{Zn}$ (Figure 2). Concentrations corrected to $5 \%$ Al reach a maximum at $12 \mathrm{~cm}: 0.14 \mu \mathrm{g} / \mathrm{g}$ for cadmium , $98 \mu \mathrm{g} / \mathrm{g}$ for zinc. These concentrations are near OSPAR background reference values [27] which are 0.2 and $90 \mu \mathrm{g} / \mathrm{g}$ (Table 1). Concentrations decrease away from this maximum. At the bottom of the core the normalized concentrations of $\mathrm{Cd}$ and $\mathrm{Zn}$ are 0.09 and $80 \mu \mathrm{g} / \mathrm{g}$, respectively. This is less than OSPAR reference values for $\mathrm{Cd}$ and $\mathrm{Zn}$ and indicates that OSPAR background reference values are somewhat overestimated for $\mathrm{Cd}$ and $\mathrm{Zn}$ in this area. Sediments from other parts of the bay of Biscay (Plateau des Landes, plateau Aquitain, $\left(44^{\circ} 09^{\prime} \mathrm{N} 22^{\circ} 20^{\prime} \mathrm{W}\right.$, $43^{\circ} 49^{\prime} \mathrm{N} 2^{\circ} 03^{\prime} \mathrm{W}$ ) show similarly low levels of $\mathrm{Cd}: 0.1 \mu \mathrm{g} / \mathrm{g}$ in deepest levels [28].

Cadmium concentrations increase continuously from $28 \mathrm{~cm}(0.09 \mu \mathrm{g} / \mathrm{g})$ to $12 \mathrm{~cm}(0.14 \mu \mathrm{g} / \mathrm{g})$; the bottom of the mixed layer is $5 \mathrm{~cm}$ down from the sediment surface (Figure 3). Taking into account the sedimentation rate $(0.56 \mathrm{~cm} / \mathrm{y}$.) these layers left the mixed box $(28-5) / 0.56=41$ and $(12-5) / 0.56=12$ years before sampling. This shows that although they remained low, $\mathrm{Cd}$ concentrations in sediment of station 10 have been growing from the end of the fifties (1999$41=1958)$ to the late eighties(1999-12=1987). At that time, they began to decrease until the sampling date (1999).

Both zinc and cadmium present rather low concentrations in core 10, despite the vicinity of the Gironde, which is very contaminated by these elements [1], [2]. These metals encompass thorough desorption in this estuary, where the salinity gradient is important and the residence time of particles is very long (>1year) [3]. The existence of fluid mud generates strong redox gradients. This helps the degradation of organic matter and the destruction of sorption sites by dissolution of iron and manganese oxyhydroxydes, which enhances metals solubilization [29]. [30] [31]. These phenomena cause the particulate $\mathrm{Cd}$ concentration to be very low in the Gironde outlet in winter and somewhat higher in spring and summer,when primary production grows up [32]. Moreover, during their transit to the West Gironde mud patch, the particles are still submitted to a high chloride activity, which causes a supplementary desorption of $\mathrm{Cd}$, from particles, leading to low $\mathrm{Cd}$ concentratrions in these particles before deposit.

After correction to $5 \% \mathrm{Al}$ the zinc profile (Figure 2) is very similar to that of cadmium, including the existence of a relative maximum at $12 \mathrm{~cm}$ depth (Figure 2). The corrected concentrations vary between 80 and $98 \mu \mathrm{g} / \mathrm{g}$ and are therefore close to OSPAR background levels. Like for cadmium, a similar conclusion can be drawn: zinc inputs to the sediment started to increase in the late fifties and began to decrease at the end of the eighties. The similarity of profiles of $\mathrm{Zn}$ and $\mathrm{Cd}$ suggests that these elements have the same origin. . A core taken in the Gironde [17] shows an evolution of $\mathrm{Cd}$ and $\mathrm{Zn}$ similar to that observed on Core 10. Concentrations began to increase in 1950, maintained an elevated level between 1963 and 1977, and after a singular peak value in 1980, began to decrease until 1999. This evolution is explained by successive changes in the activity of an industrial site situated far upstream (400km ), with mining, zinc ore (blende) treatment, and foundry. This evolution is quite similar to the evolution observed on core 10 if we take into account the important distance between the two stations (Bordeaux 60 nautical miles in the inner Gironde estuary, and Station10, 18 nautical miles off the mouth of the estuary ), which may explain the time shift between the two profiles (about 10 years).

\subsubsection{Other metals.}

Chromium (49 to $54 \mu \mathrm{g} / \mathrm{g}$ ), nickel (23 to $30 \mu \mathrm{g} / \mathrm{g}$ ), copper (10 to $11 \mu \mathrm{g} / \mathrm{g}$ ) mercury $(0.045$ to $0.061 \mu \mathrm{g} / \mathrm{g}$ ) and lead (26 to $30 \mu \mathrm{g} / \mathrm{g}$ ) corrected concentrations are clearly below ( $\mathrm{Cu}, \mathrm{Ni}, \mathrm{Cr}$ ) either very close $(\mathrm{Pb}, \mathrm{Hg}$,$) to the OSPAR reference values (Tableau 1)$. All these elements 
present low values and uniform profiles (figure2) which does not suggest any inputs to the sediment during the time of deposition.

\subsection{Core 17}

\subsubsection{Description and dating}

This core has been sampled in the Capbreton canyon in more than $500 \mathrm{~m}$ water depth. The sediment is a homogeneous mud, which looks anoxic from the horizon 1-2 $\mathrm{cm}$ to the bottom of the core $(30 \mathrm{~cm})$. The horizon $0-1 \mathrm{~cm}$ contains many worm burrows. An echinoderm is noticed in the upper layers. The particles size is homogeneous on the profile (88.4 to $94.3 \%$ of particles less than $63 \mu \mathrm{m}$ (Figure 5).

Aluminium concentrations are almost constant between $15 \mathrm{~cm}$ and the bottom of the core (about $7 \%, 70000 \mu \mathrm{g} / \mathrm{g}$, Figure 5). They are more variable between the surface and $15 \mathrm{~cm}$, which is surprising as granulometry and water content are nearly constant in these layers.. The water percentages are homogeneous on the first 5 centimetres (60\%) and then decrease slowly to $50 \%$ at the bottom of the core. This small change has not been taken into account in estimating the sedimentation rate.

Iron (2.7 to3\%) and manganese(365 to $424 \mu \mathrm{g} / \mathrm{g}$ ) normalized concentrations vary little along the profile (Figure 5). This suggests that the diagenetic phenomena due to redox processes are negligible on this profile and that anoxic conditions prevail all along the core. The organic carbon concentrations are elevated (between 2.2 and $2.4 \%$ ) and uniform throughout the profile.

The profile of unsupported ${ }^{210} \mathrm{~Pb}$ (Figure 6) does not show any strong trend in the first levels ( 0 to $4 \mathrm{~cm}$ ) which is the sign of a mixed layer. In the following levels (from $4 \mathrm{~cm}$ to the bottom), the relationship between ${ }^{210} \mathrm{~Pb}$ (in $\mathrm{Bq} / \mathrm{kg}$ ) and depth in $\mathrm{cm}(\mathrm{Z})$ is very tight and described by the regression equation $\ln { }^{210} \mathrm{~Pb}=-0.025 Z+6.20\left(R^{2}=0.98 \mathrm{n}=4\right)$ Reasoning as for core 10 this relation provides the deposition rate: $\mathrm{K}=\ln 2 /(0.025 * 22.2)=1.2 \mathrm{~cm} /$ year.

The deepest layer $(30 \mathrm{~cm})$ went through a $30-4=26 \mathrm{~cm}$ course since it was out of reach of external inputs. This means that last influence of inputs on this layer occured 26/1.2=21.6 years before1999, which means around 1977. So this core describes the evolution of inputs to the sediment from1977 to 1999 . Indeed significant activities of ${ }^{137} \mathrm{Cs}$ are recorded all along the core. This means that all the layers are deposited after the first atmospheric thermonuclear blasts in the early fifties.

\subsubsection{Cadmium}

The three deepest horizons have the lowest normalized concentrations $(0.16 \mu \mathrm{g} / \mathrm{g})$ : lower than the OSPAR reference $0.2 \mu \mathrm{g} / \mathrm{g}$ (Tableau .1), but higher than the lowest value of Core $10(0.09 \mu \mathrm{g} / \mathrm{g})$.It is also lower than the mean background value found in estuarine and coastal sediments of the Basque country (table 1) [33]. A significant increase is observed between $24 \mathrm{~cm}$ and $10 \mathrm{~cm}$ from the surface, where the normalized concentration reaches $0.22 \mu \mathrm{g} / \mathrm{g}$. Starting from the horizon $10 \mathrm{~cm}$ concentrations decrease to the surface where they reach $0.18 \mu \mathrm{g} / \mathrm{g}$.

The horizon $24 \mathrm{~cm}$ was at the bottom of the mixed layer four centimetres under the surface (24-4)/1.2=16.7 years before sampling, which means around 1982.

The horizon $10 \mathrm{~cm}$ has been buried under $10-4=6 \mathrm{~cm}$ of more recent sediment since it was at the bottom of the mixed layer. This took around 6/1.2=5 years. So the horizon $10 \mathrm{~cm}$ became out of reach of external inputs in 1994.

Finally, this profile indicates that from a low value in the late seventies (bottom of the core) cadmium inputs to sediment kept increasing until the mid nineties (circa 1994), when they were very similar to the OSPAR and Pays Basque [33] background level. From that time a continuous decrease was observed until 1999. 


\subsubsection{Mercury}

The normalized concentrations are very high throughout the core: 0.5 to $0.7 \mu \mathrm{g} / \mathrm{g}$ (Figure 5), which is more than ten times the OSPAR baseline $(0.05 \mu \mathrm{g} / \mathrm{g}))$. This is also much higher than the mean background of the Basque coastal and estuarine area, $(0.13 \pm 0.05 \mu \mathrm{g} / \mathrm{g})$ [33]. From the horizon $28 \mathrm{~cm}$ the concentrations increase, reflecting significant inputs. This may be timed (28-4)/1.2=20 years before sampling, in 1979. This trend is reversed on the horizon $12 \mathrm{~cm}$ or (12-4)/1.2=6.6 years before sampling, circa 1992. While this date marks a significant drop in inputs, concentrations remain elevated all along the core. Nevertheless we must temper this by noting that part of the mercury burden can be explained by high concentration of organic carbon in core 17 , as $\mathrm{Hg}$ is usually associated with Organic carbon. Actually the average organic carbon concentration is $23.3 \mathrm{~g} / \mathrm{kg}$ versus 12.7 in core 10 .

\subsubsection{Lead}

The normalized concentrations increase steadily from $69 \mu \mathrm{g} / \mathrm{g}$ at the bottom of the core to $78 \mu \mathrm{g} / \mathrm{g}$ on the horizon $6 \mathrm{~cm}$ (Figure 5). The values observed throughout the profile are more than twice the reference value $(25 \mu \mathrm{g} / \mathrm{g})$ given by OSPAR and the local reference $(31 \mu \mathrm{g} / \mathrm{g})$ given by Rodriguez et al. [33] for the estuarine and coastal environment in the Basque country. This shows an input of contaminant prior to 1977 . From the horizon $4-5 \mathrm{~cm}$ upwards, a significant decline is observed. This horizon is $1 \mathrm{~cm}$ from its exit from the mixed layer. It was therefore at the basis of this layer about a year before the sampling, which means in 1998. This year seems to mark the beginning of a strong decline of lead inputs, as it can be observed despite the intense mixing in the mixed layers of the core. This happened probably in connection with the ban of leaded gasoline in Europe. However, this calculation is made on small time interval (1 year), so this result, must be viewed as preliminary.

\subsubsection{Zinc}

Normalized concentrations are slightly more than OSPAR reference values, and less than the mean local background of $174 \mu \mathrm{g} / \mathrm{g}$ [33]. They show a slow increase in layers between 28 $\mathrm{cm}(134 \mu \mathrm{g} / \mathrm{g})$ and $10 \mathrm{~cm}(150 \mu \mathrm{g} / \mathrm{g})$. The concentrations then decrease steadily to $122 \mu \mathrm{g} / \mathrm{g}$ in surface (Figure 5). The increase starting point is situated $28-4=24 \mathrm{~cm}$ under the limit of the mixed layer. So this sediment got out of reach of external inputs 24/1.2=20 year before sampling, in 1979. In the same way the horizon $10 \mathrm{~cm}$ received decreasing external inputs (10-4)/1.2=5years before sampling. So it appears that zinc concentrations began to increase on station 17 around 1979 and the decrease began around1994. All concentrations are less than the mean background of the estuaries and coastal areas in the basque country. [33]

\subsubsection{Copper.}

Normalized concentrations go from $19.7 \mu \mathrm{g} / \mathrm{g}$ at the bottom to $19 \mu \mathrm{g} / \mathrm{g}$ in surface after passing by a maximum of $24 \mu \mathrm{g} / \mathrm{g}$ on the horizon $10 \mathrm{~cm}$. The copper profile is rather similar to the zinc and cadmium profile which suggests an anthropic origin.. The inputs decrease (beginning $10 \mathrm{~cm}$ from the surface), may be located around 1994 as for $\mathrm{Zn}$ and Cd. All concentrations are low. Only the shape of the profile (existence of a maximum) suggests that this site has been for some time subjected to moderate inputs of copper.

\subsubsection{Chromium}

The normalized chromium concentrations vary between 51 and $61 \mu \mathrm{g} / \mathrm{g}$. These values are comparable to the OSPAR reference value. In a way similar to cadmium and zinc a slight maximum is observed on the horizon $10 \mathrm{~cm}$. This suggests a decrease of inputs of chromium around 1994. 


\subsubsection{Nickel}

Normalized concentrations are $23.8 \mu \mathrm{g} / \mathrm{g}$ at the bottom and $22.3 \mu \mathrm{g} / \mathrm{g}$ in surface. They reach a minimum of $21.4 \mu \mathrm{g} / \mathrm{g}$ at $15 \mathrm{~cm}$ depth. They are well below the OSPAR ad local reference values, and almost equal to the concentrations of core 10. No nickel input seems to have occurred on this station during the time interval recorded by this core.

Despite an intense mixing revealed by the ${ }^{210} \mathrm{~Pb}$ profile (Figure 6 ), $\mathrm{Pb}, \mathrm{Cd}, \mathrm{Cu}, \mathrm{Zn}$, and $\mathrm{Hg}$ show a decreasing profile in the mixed layer (Figure 5). This is the sign of a strong decrease in metal inputs to sediment during the last years before 1999, albeit concentrations remain high for $\mathrm{Hg}$ and $\mathrm{Pb}$.

Estuaries from the Basque country export large quantities of contaminted suspended particles to the southeastern Bay of Biscay. Once they are deposited, they constitute a very big potential source of sediments and associated contaminants for the Capbreton canyon [34]. The similar evolution of the $\mathrm{Cd}, \mathrm{Cu}, \mathrm{Zn}$ and $\mathrm{Hg}$ profiles suggests an anthropic origin, showing increasing inputs in the seventies and decreasing trend in the last years of the century.

This is in accordance with the historical evolution of the industrial landscape in northern Spain, where ore treatment and metal industries developed in the last part of the $19^{\text {th }}$ century and began to decay in the late $20^{\text {th }}$ century, in relation to environmental policies, development of waste treatement systems and closure of major factories for economical reasons [35].

\section{Conclusion}

This study shows that dated cores are an efficient tool to assess the temporal evolution of metal contamination of sediment, provided sediments are not mixed and dating is possible. The core sampled off the Gironde (Station10) showed low concentrations of all metals in the bottom layers, deposited in the late 50's. A continuous increase of concentration is observed for cadmium and zinc until the late 80's. Nevertheless, they always remain moderate. No significant variation was observed for other metal concentrations which remained very moderate. This shows that despite an important metal contamination of the Gironde estuary [36], [37], the sediment of the nearby continental shelf remains relatively free from contamination

In the Capbreton canyon, Core 17 shows a much more contaminated sediment. Mercury and lead normalized concentrations are much higher than OSPAR and Basque littoral references . Mercury concentrations were slightly increasing from the bottom of the core (late 70's) to 12 $\mathrm{cm}$ under the surface of the sediment (early 90's). Then a continuous decrease was observed, even though concentrations remained very high.

Lead concentrations have been slowly growing from the late 70's to the early 90's. Then they began to decrease, but they remain twice the OSPAR and Basque reference value.

Zinc does not appear in large excess Other metal concentrations $(\mathrm{Cd}, \mathrm{Cu}, \mathrm{Cr}, \mathrm{Ni}$,) are quite comparable to OSPAR and local reference values.

These two cores show that in the two regions studied (West Gironde mud patch, Capbreton canyon) metal concentrations are clearly decreasing with time, having reached a maximum on the 1970's., except for Ni. This is particularly significant in the Capbreton canyon, where heavy metallic contamination is still observed. There is an encouraging environmental impact of the abatement measures that decrease contaminant fluxes to the coastal environment. 


\section{References}

[1] J.M. Jouanneau, J.M., B. Boutier, J.F. Chiffoleau, C. Latouche, and I. Philipps. Cadmium in the Gironde fluvioestuarine system: behaviour and flow. Science of The Total Environment 97-98 (1990), pp. 465-479.

[2] F. Elbaz-Poulichet, W.W. Huang, J. Jednacak-Biscan, J.-M. Martin and A.J. Thomas. Trace metals behaviour in the Gironde estuary: The problem revisited. Thalassia Jugosl. 18 (1982), pp. 61-95.

[3] A.M.L. Kraepiel, J.F. Chiffoleau, J.M. Martin, and F.M.M. Morel. Geochemistry of trace metals in the Gironde estuary Geochimica et Cosmochimica Acta 61, (7) (1997), pp.1421-1436

[4] M.J. Belzunce,_ O. Solaun, J. Franco, V. Valencia, , A. Borja. Accumulation of organic matter, heavy metals and organic compounds in surface sediments along the Nervion Estuary (northern Spain) Marine Pollution Bulletin, 42, (12) (2001), pp.1407-1411.

[5] O. Solaun, M.J. Belzunce,J. Franco,V. Valencia \& A. Borja . Acumulacion de contaminantes en los sedimentos superficiales del estuario del Nervion (golfo de Bizkaia).

In :Oceanographie du golfe de Gascogne. VIleme Colloq. Int.,Biarritz,4-6 avril 2000. ElbéeJ.(d') \& Prouzet P.(coord.) Ed.Ifremer, Actes Colloq.(2001) pp. 313, 318.

[6] N. Valette-Silver. The use of sediment cores to reconstruct historical trends in contamination of estuarine and coastal sediment. 1993. Estuaries 16, 3B (1993) pp. 577-588.

[7] A.P. Karageorgis,.,H.Isaberi,., N.B. Price, , G.R.P.Muir, , J.M. Pates, V.Lykousis. Chemical composition of short sediment cores from the Thermaikos Gulf (Eastern Mediterranean): sediment accumulation rates, trawling and wind minnowing effects. Continental Shelf Research 25 (2005), pp. 2456-2475.

[8] E.D. Goldberg, E. Gamble, J.J. Griffin, and M. Koide. Pollution History of Narragansett Bay as recorded in its Sediments Estuarine and Coastal Marine Science 5 (1977) pp. 549561.

[9] B. Gaboury and T.F.Rozan.. $210 \mathrm{~Pb}$ and $137 \mathrm{Cs}$ dating methods in lakes. A retrospective study. Journal of paleolimnology 25(4) (2001) pp. 455- 465.

[10] C. Gobeil, N. Silverberg, B. Sundby, and D.Cossa. Cadmium diagenesis in the Laurentian trough sediments. Geochimica et Cosmochimica Acta (51) (1987) pp.589-596.

[11] H.M. Edenborn, A. Mucci, N. Belzile, J. Lebel, N. Silverberg, B. Sundby . A glove box for the scale subsampling of sediment box cores. Sedimentology, 33,(1986) pp.147-150.

[12] D.H. Loring, and R.T.T.Rantala,. Sediments and suspended particular matter : total and partial methods of digestion. ICES Tech. Mar. Environ. Sci. 9 (1990), 14pp.

[13] D. Cossa, M. Coquery, K. Nakhle, and D. Claisse. Dosage du mercure total et du monométhylmercure dans les organismes et les sédiments marins. Ed. Ifremer, Méthodes d'Analyse en Milieu Marin, (2002) 44p.

[14] J.F. Chiffoleau, D.Auger, B. Boutier, E. Rozuel, and I. Truquet. Dosage de certains métaux dans les sédiments et la matière en suspension par absorption atomique.Ed.Ifremer. Méthodes d'analyse en milieu marin.(2003) 45pp. 
[15] P. Pheiffer Madsen, and J. Sorensen , 1979. Validation of the lead-210 datation method. Journal of radioanalytical chemistry Vol.54, n¹-2 (1979), pp.39-48.

[16].C.A. Nittrouer, D.J. De Master, B.A. Mac Kee, N.H. Cutshall, and I.L. Larsen. The effect of sediment mixing on $\mathrm{Pb}-210$ accumulation rates for the Washington continental shelf . Mar.Geol.54 (1983-1984) pp. 201-221.

[17] F. Grousset, J.M. Jouanneau, P. Castaing, G. Lavaux, and C. Latouche. A 70 year Record of Contamination from Industrial Activity along the Garonne River and its Tributaries(SW France).Estuarine, Coastal and Shelf Science48 (1999) pp. 401-414.

[18] J.C.Ritchie and R. Mc Henry . Application of radioactive fallout Cesium-137 for measuring soil erosion and sediment accumulation rates and patterns: A review. Journal of Environmental Quality 19 (2) (1989) pp.215-233.

[19] W. C. Rember, T. W. Erdman, M. L. Hoffman, V. E. Chamberlain, and K. F. Sprenke Dating of mine waste in lacustrine sediments using cesium-137. Environmental Geology 22 (3) (1993) pp. 242-245.

[20] H.L.Windom, S.J. Schropp, F.D.Calder, J.D. Ryan, R.G. Smith, L.C. Burney, F.G. Lewis, and C.H. Rawlinson. Natural trace metal concentrations in estuarine and coastal marine sediments of the south eastern United States. Environmental Science and Technology 23(1989) pp; 314-320.

[21] D.H. Loring. Normalization of heavy metal data from estuarine and coastal sediments. ICES jounal of Marine Science, 48 (1)(1991), pp.101-115.

[22] M. Kersten, and F. Smedes,. Normalization procedures for sediments contaminants in spatial and temporal trend monitoring. J. Env. Monit. 4 (2002), pp. 109-115.

[23] OSPAR JAMP guidelines for monitoring contaminants in sediments2002

[24] D. Burdige and J.M.Gieskes. A pore water/solid phase diagenetic model for manganese in marine sediments Am.J.of Sci 283 (1983) pp. 29 - 47

[25] P. Lesueur, J.M. Jouanneau, D. Boust, J.P. Tastet , and O. Weber. Sedimentation rates and fluxes in the continental shelf mud fields in the Bay of Biscay (France). Continental Shelf Research 21 (2001) pp. 1383-1401.

[26] W.H. Berger, and G.R.Heath. Vertical mixing in pelagic sediments. Journal of marine research, 26 (2) (1968) pp. 134 - 143.

[27] OSPAR 2005 Agreement on Background Concentrations for Contaminants in Sea water,Biota and Sediment (OSPAR agreement 2005-6. OSPAR Commission reference number 2005-6.

[28] G.Chaillou, P. Anschutz, G. Lavaux, J. Schafer, G. Blanc. The distribution of Mo, U, and $\mathrm{Cd}$ in relation to major redox species in muddy sediment of the bay of Biscay. Marine Chemistry 80 (2002) pp. ( 41-59).

[29] S. Robert, G. Blanc, J.M. Jouanneau, J. Schafer, G. Lavaux, and G. Abril.Metral mobilization in the Gironde estuary (France) :the role of the Soft Mud layer in the Maximum Turbidity Zone. Marine Chemistry 87 (2004) pp. 1-13. 
[30] H. Etcheber, J.M. Jouanneau,C. Latouche, P. Azoeuf, A.Caillot, and R.Hoslin. Expérience «double marquage de vase en Gironde ».Contribution à la connaissancedu devenird'une pollution métallique en estuaire. Oceanologica Acta 3 (1980), 4, pp. 477-486.

[31] J.J.G. Zwolsman, B.T.M. Van Eck, and C.H. Van Der Weijden. Geochemistry of dissolved trace metals (cadmium, copper, zinc) in the Scheldt estuary, Southwestern Netherlands : Impact of seasonal variability. Geochimica et Cosmochimica Acta 61 (1997) 8 pp.1635-1652.

[32] B. Boutier, P. Michel, J.F. Chiffoleau, D. Auger, and E. Chartier, 2001. Comportement du cadmium issu de la Gironde sur le plateau continental. Influence des apports girondins sur les zones cotieres adjacentes. In :Vlle colloq. Int., Biarritz, 4-6 avril 2000. Elbée J.(d') \& Prouzet P. (coord.) Ed. Ifremer, Actes Colloq, 31, 66-71

[33] J.G. Rodriguez, I. Tueros, A. Borja, M.J. Belzunce, J. Franco, O. Salaun, V. Valencia, and A. Zuazo. Maximum likelihood mixture estimation to determine metal background values in estuarine and coastal sediments within the EuropeanWater Framework Directive. Science of the Total Environment 370 (2006) pp. 278-289.

[34] J.-M. Jouanneau, O. Weber, N. Champilou, P. Cirac, I. Muxika, A. Borja,A. Pascual, J. Rodriguez-Lazaro, and $O$. Donard Recent sedimentary studyof the shelf of th Basque country.Journal of Marine Systems 72 (1-4) 2008 pp397-406

[35] J. Franco, A. Borja, and V. Valencia. Overall assessment - Human impacts and quality status. In: Oceanography and Marine Environment of the Basque Country (2004) Chap.23 pp $582-597$

[36] P.Michel, B. Boutier, and J.F.Chiffoleau. Net fluxes of dissolved Arsenic, Cadmium, Copper, Zinc, Nitrogen and Phosphorus from the Gironde estuary (France): seasonal variations and trends. Estuarine Coastal and Shelf science 51 (2000) pp. 451- 462.

[37] B. Boutier, J.F. Chiffoleau, J.F., J.L. Gonzalez, J.L., P. Lazure, P.,D. Auger, D., and I.Truquet, I., Influence of the Gironde estuary outputs on cadmium concentrations in the coastal waters : consequences on the Marennes Oleron bay (France). Oceanologica Acta 23 (7)( 2000) pp. 745-755 
Tables

\begin{tabular}{|l|l|l|l|l|l|l|l|}
\hline & $\mathrm{Cd}$ & $\mathrm{Cr}$ & $\mathrm{Cu}$ & $\mathrm{Pb}$ & $\mathrm{Hg}$ & $\mathrm{Ni}$ & $\mathrm{Zn}$ \\
\hline O.S.P.A.R. [27] & 0.2 & 60 & 20 & 25 & 0.05 & 30 & 90 \\
\hline Basque Country [33] & 0.24 & 26 & 33 & 31 & 0.13 & 29 & 174 \\
\hline
\end{tabular}

Table 1 Metal background concentrations in sediment, dry weight, mg/kg

\section{Figures}

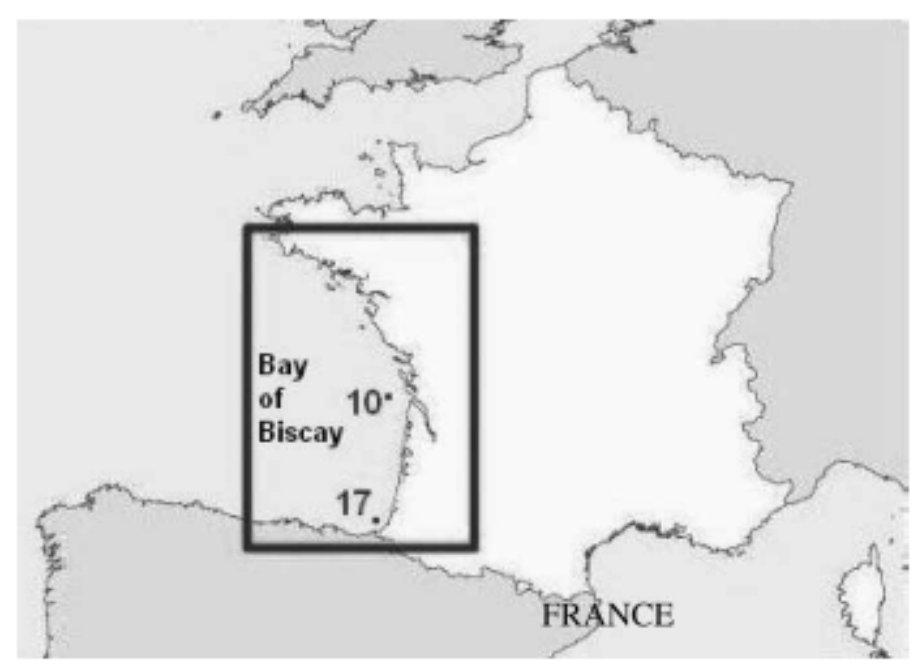

Figure1. Location of the cores 10 and 17. 

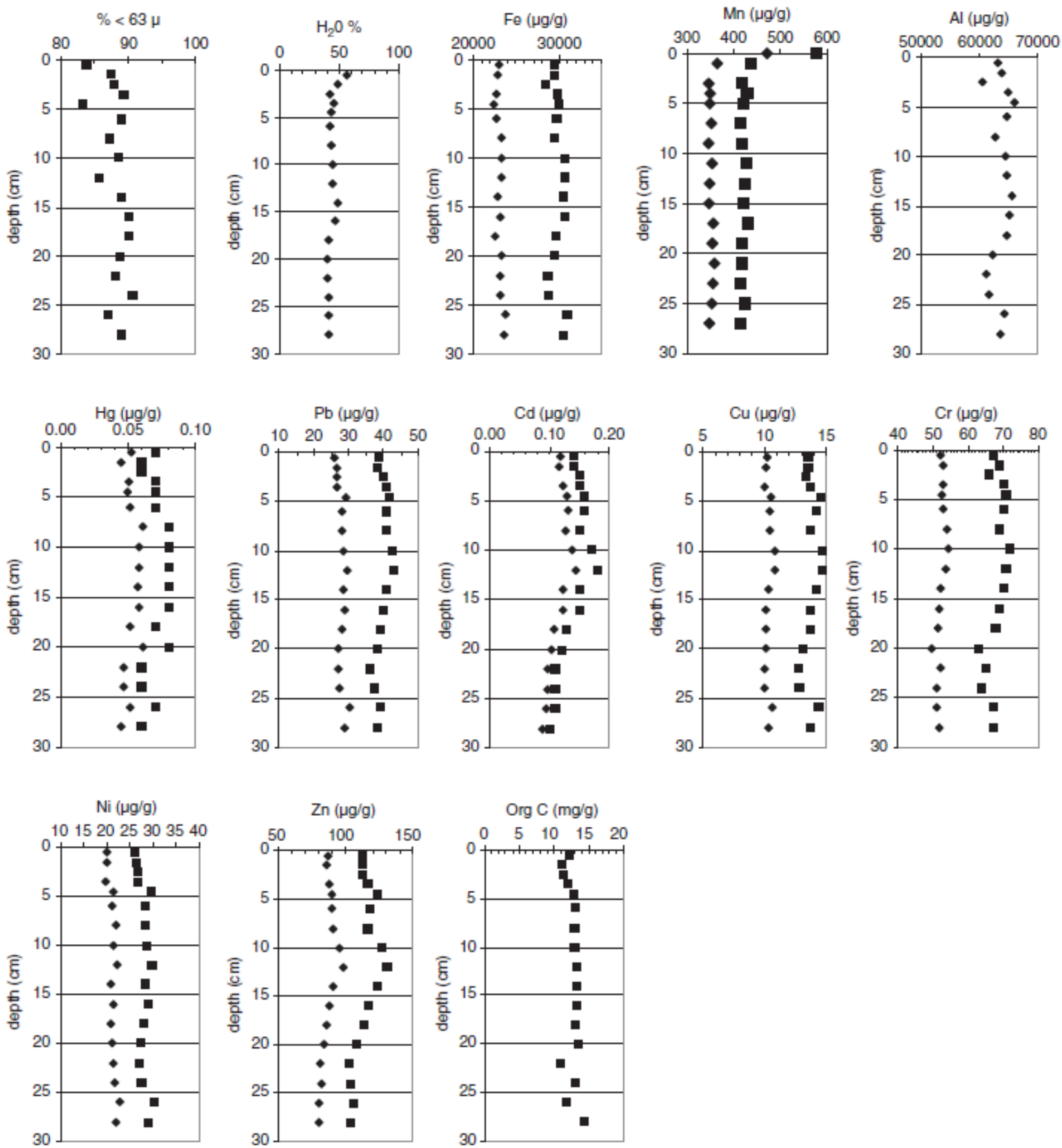

Figure 2. Metal concentrations and general parameters in core $n^{\circ} 10$

$\checkmark$ Normalized data $\mathbf{R}$ Raw data 


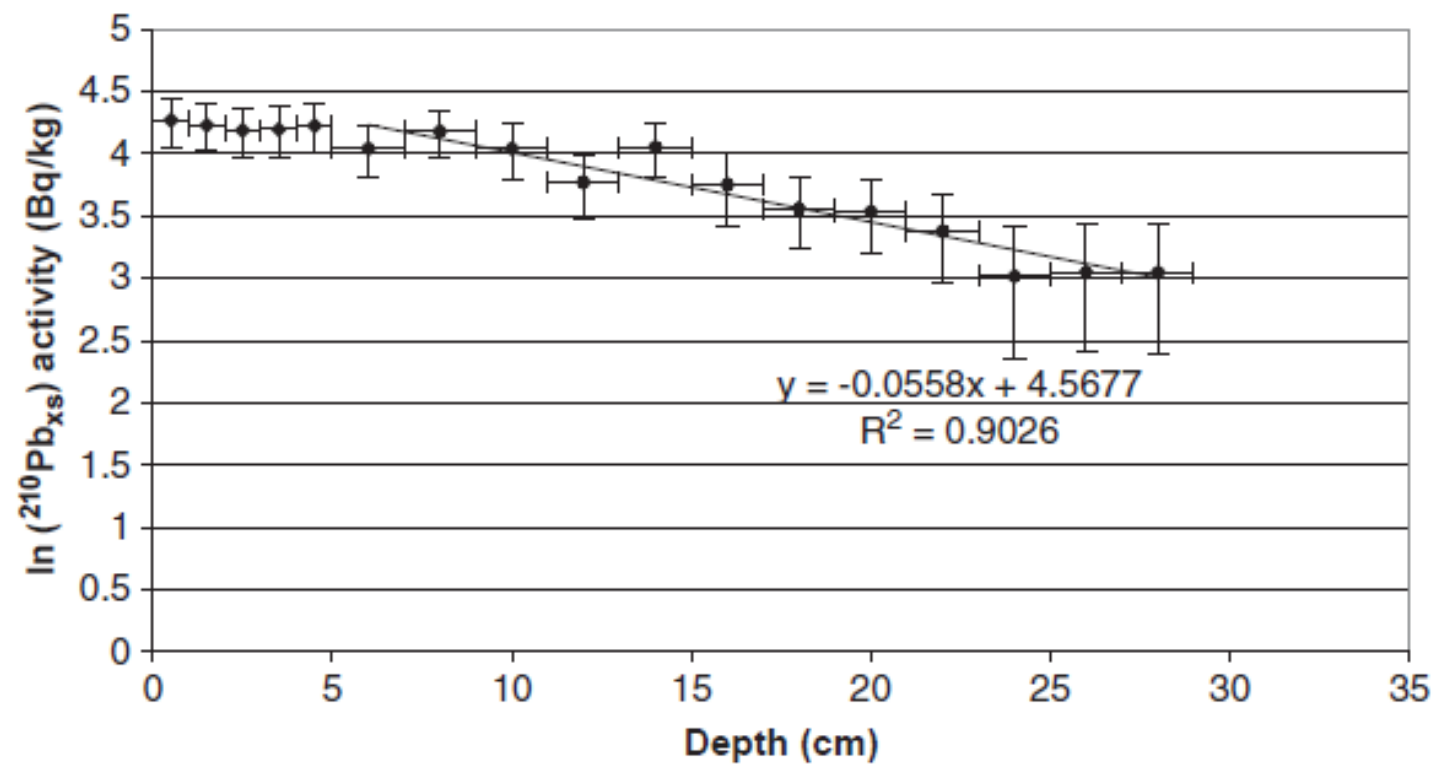

Figure 3 Neperian logarithm of unsupported ${ }^{210} \mathrm{~Pb}_{\mathrm{xs}}$ activity $(\mathrm{Bq} / \mathrm{kg})$, dry weight, vs depth in core 10.

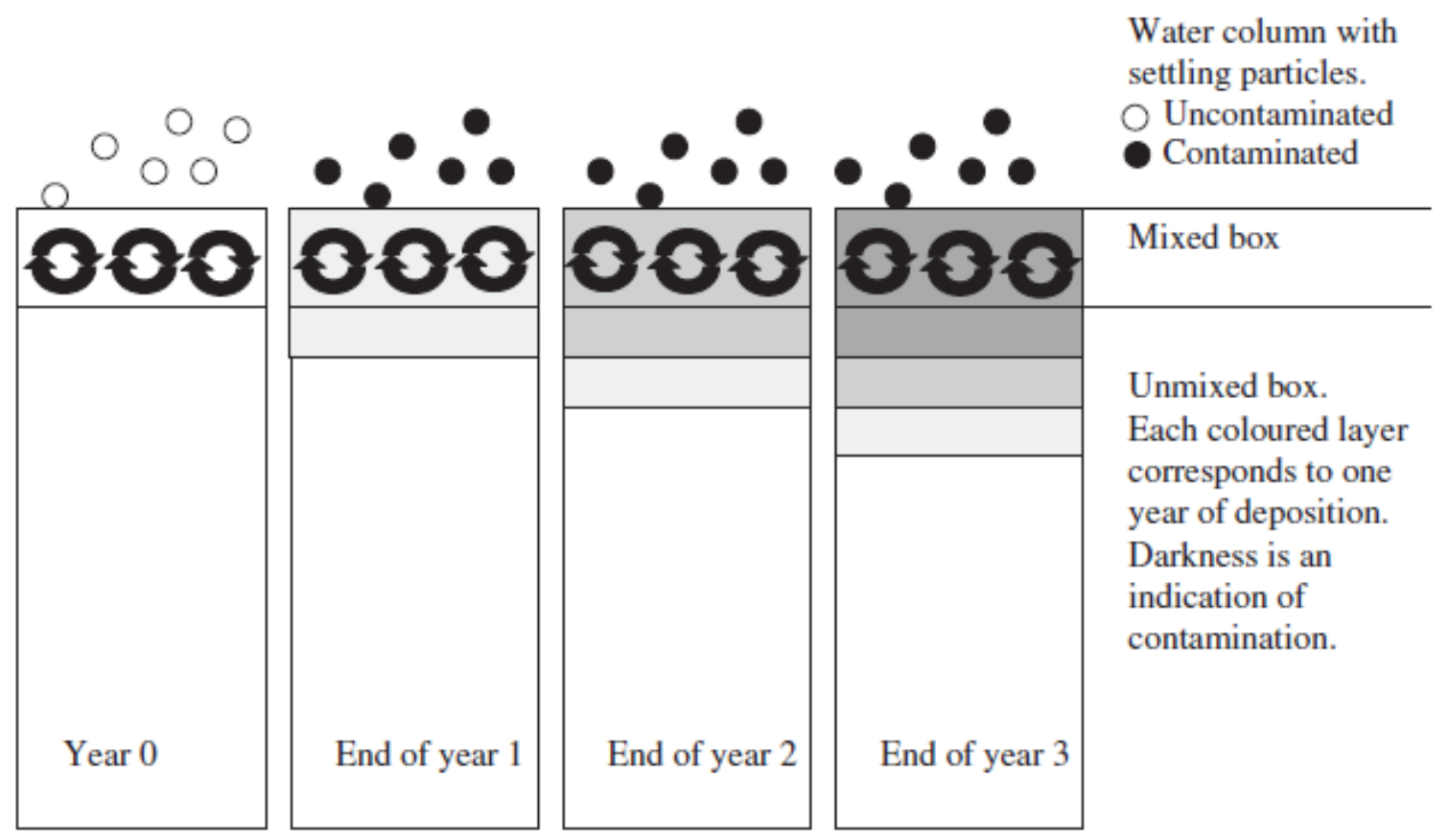

Figure 4 Two box representation of cores 10 and 17 . Black settling particles are contaminated, white ones are not. Their mixing with sediment causes the surface layer to become darker and darker. 

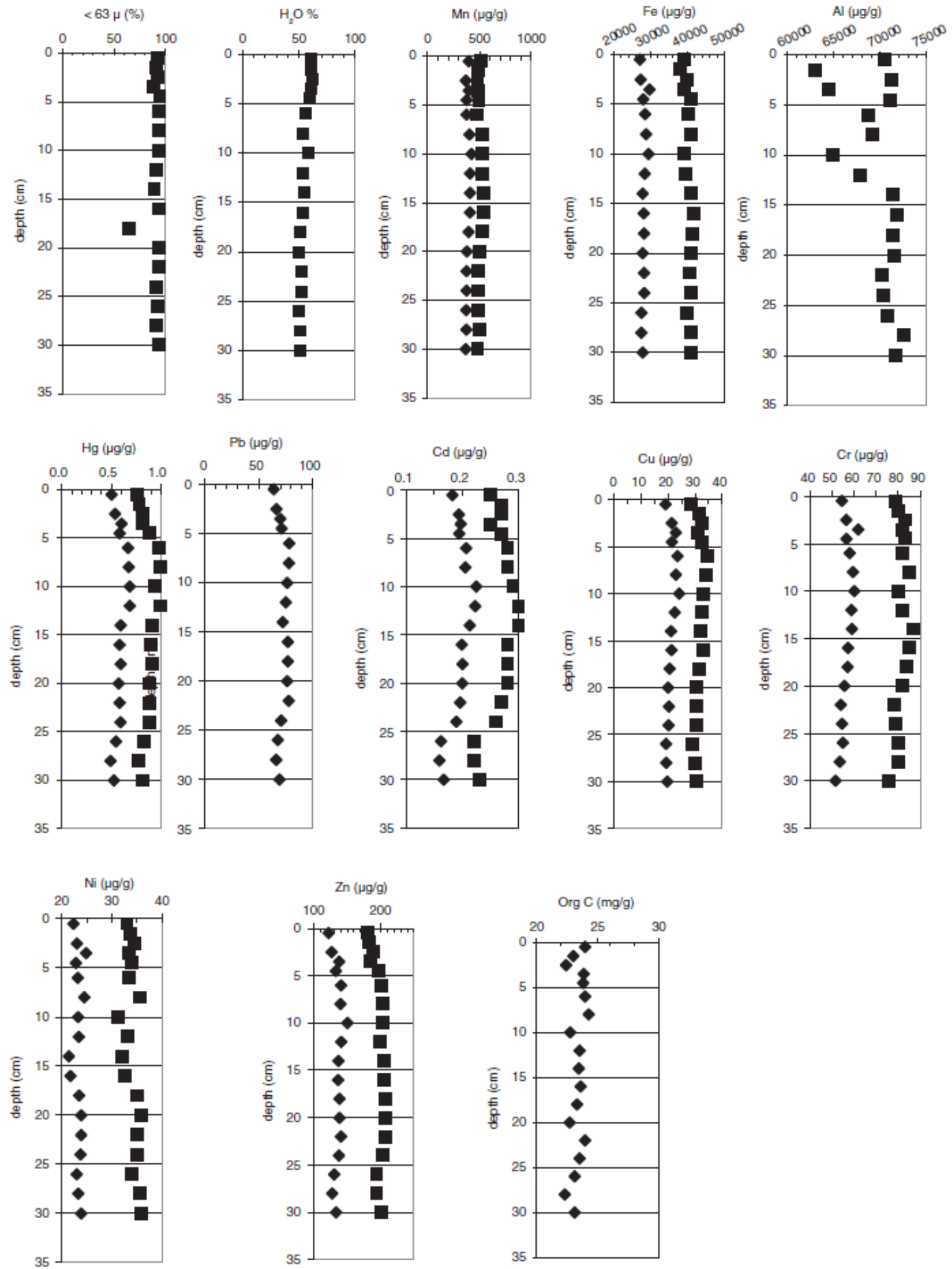

Figure 5. Metal concentrations and general parameters in core $\mathrm{n}^{\circ} 17$

- Normalized data Raw data 


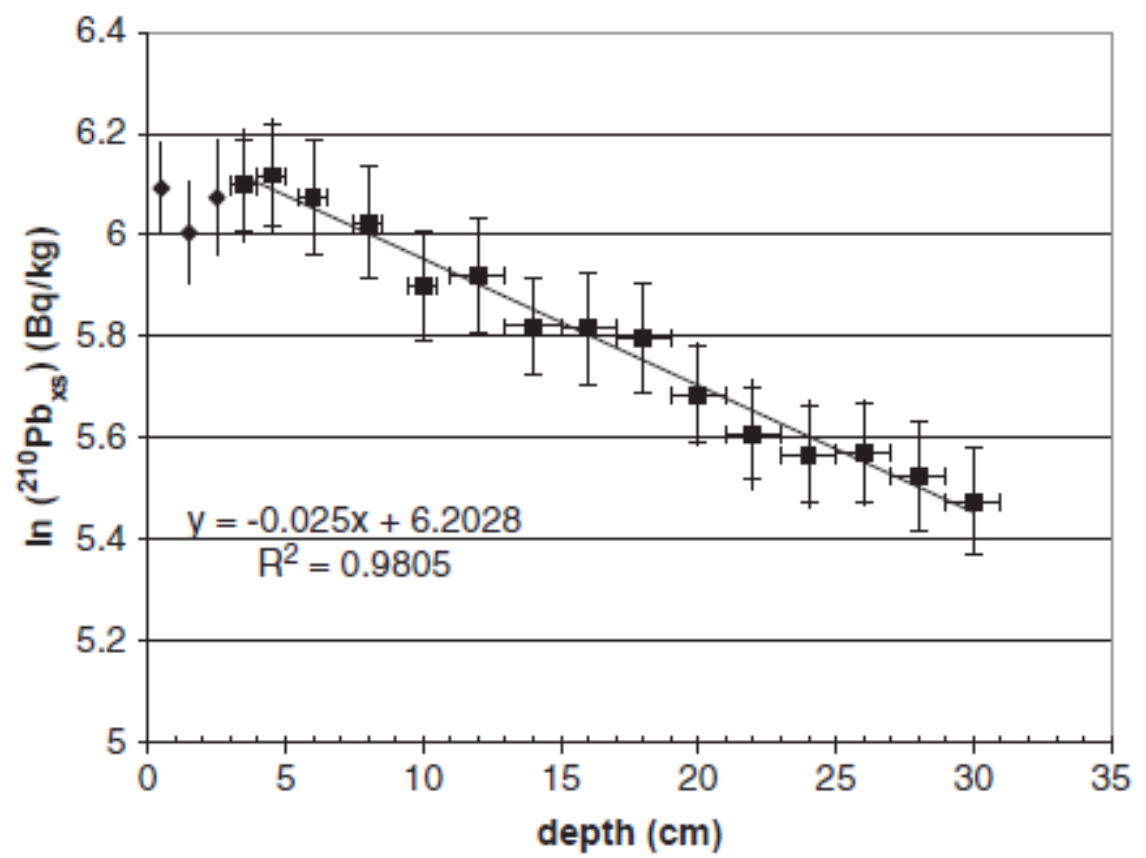

Figure 6 Neperian logarithm of unsupported ${ }^{210} \mathrm{~Pb}_{\mathrm{xs}}$ activity $(\mathrm{Bq} / \mathrm{kg})$, dry weight, vs depth in core 17. 